\title{
From too little money to too much?
}

The annual allocation of funds between the British research councils is a more cheerful event this year than in the recent past. But money by itself will not put British research back on its feet.

IF it was true in the early 1980 s that " $£ 500$ million is a lot of money", then how much more is $£ 897$ million now? The numbers are the sums available to the British research councils in 1980 and in the financial year beginning next April (see page 199). The second sum will be further augmented by the transfer of $£ 70$ million from the recurrent budget of the universities. The quotation is that with which the Prime Minister, Mrs Margaret Thatcher, dealt with those who used to complain that British science was starved of funds. Apocryphal or otherwise, Thatcher's riposte was always correct, while now the best part of $£ 1,000$ million is indeed a lot of money. But that only goes to show that what is wrong with British science is not that funds are hard to come by.

Ten years ago, the outstanding trouble was that a previous decade of restraint had left too little slack in the support system to allow bold initiatives a decent chance of attracting funds. The past decade has created two further causes of decline - the diversion of funds that might have been spent on research to the premature retirement of able people and the continuing distraction of academic researchers by the impoverishment and enforced upheaval of their institutions. That is why the prospect that there will now be a real (as distinct from inflationary) increase in the funds available for research in Britain, welcome though it is, will not put the British research enterprise to rights. Uncertainty persists in many important ways, too great a proportion of the funds now available is pre-assigned and the unambitious tradition of the past decade exerts a baleful influence.

Uncertainty? On the face of things, now that major questions such as continued British membership of the European high-energy physics laboratory at Geneva (called CERN) have been settled, what doubts can there be in people's minds about the future? Sadly, there are several, of which the most conspicuous lies most squarely at the British goverment's own door. It is now nearly a year since a committee appointed by the Advisory Board for the Research Councils (ABRC) recommended that the five existing research councils should be merged. The objective was to settle boundary disputes between the councils, notably the wish of the Medical Research Council to be predominantly responsible for supporting research in biology, application as well as discovery. Much of 1989 was given over to argument over this proposal. ABRC's opinion was delivered to the government the same year. But nothing has yet been decided. Whitehall complains that science cannot take decisions for itself, but the government is no better.

The over-commitment of resources to fixed enterprises is little changed. Of the $£ 76$ million extra available next year, only $£ 1.7$ million will be spent on research grants in what is called the research councils' "responsive mode" (which means that they have not themselves specified the topics). And three-quarters of the extra $£ 11$ million to be spent next year on manpower training will be used to increase the stipends of government-supported research students by a long overdue $£ 600$ a year. There is no vision, in ABRC's advice, of a time when it will again be possible for people, most probably young people, to recruit help, and the funds with which to pay for it, in the pursuit of a daring project in research.

That, of course, is the tradition of the past decade with which British science is now lumbered. It is understandable, after a decade in which mere survival seemed at risk, that the preservation of each and every going concern should seem worthwhile. The fault, in such a policy, is that good ideas (still plentiful) and excellent research (which still abounds) fail to make a mark in an increasingly competitive environment, now more than ever. The managers of the research enterprise have been slow to recognize this truth. They should appreciate that one of their most urgent needs is to find a few fields of enquiry in which British science remains expert and in which, with generous support, it could win the reputation of being preeminent. But why? Not for kudos, or out of altruism, but from the simple recognition that the flight of young people from science on leaving British schools and universities will only be redressed when there are some tangible examples of how even a poorly-paid profession, such as research in Britain, can still bring rewards.

\section{Plague upon plague}

The British decision to back research on slow virus dieases is prudent, not a sign of impending crisis.

BOVINE spongiform encephalopathy (BSE) is a disease of cattle apparently similar to scrapie, which afflicts sheep. There is a suspicion that scrapie may transfer to cows in the British farming practice of using unwanted offal from 